\title{
PROSA DAN PUISI RAKYAT SUKU REJANG KECAMATAN MUARA KEMUMU KABUPATEN KEPAHIANG
}

\author{
Rudi Hartono, Sarwit Sarwono, dan Agus Joko Purwadi \\ Program Studi Pendidikan Bahasa Indonesia \\ Jurusan Pendidikan Bahasa dan Seni \\ FKIP Universitas Bengkulu \\ rudih0807@gmail.com
}

\begin{abstract}
Abstrak
Tujuan penelitian ini adalah mengelompokkan prosa dan puisi rakyat yang ada di Kecamatan Muara Kemumu Kabupaten Kepahiang. Metode penelitian yang digunakan, yaitu metode etnografi. Data dalam penelitian ini berupa prosa dan puisi rakyat suku Rejang Kecamatan Muara Kemumu Kabupaten Kepahiang. Data dianalisis mengikuti prinsip alih ide dengan bukan menerjemahkan kata demi kata. Hasil penelitian menunjukkan terdapat tujuh prosa rakyat dan 13 puisi rakyat di Kecamatan Muara Kemumu Kabupaten Kepahiang. Prosa rakyat yang terdapat di Kecamatan Muara Kemumu yaitu: (1) Asal Mula Batu Kalung, (2) Hantu WakWir, (3) Benuang Sakti, (4) Bloloi, (5) Asal Usul Rejang Pat Petulai, (6) Asal Usul Buah Jagung, (7) Kancil Ingkar Janji. Puisi rakyat yang terdapat di Kecamatan Muara Kemumu adalah berupa: pantun, ungkapan tradisional (peribahasa), dan mantera yang telah penulis kelompokkan sesuai panduan Danadjaja.
\end{abstract}

Kata kunci: Prosa, puisi rakyat, suku Rejang, Kepahiang.

\begin{abstract}
The purpose of this study is to classify folk prose and poetry in Muara Kemumu District, Kepahiang District. The research method used is the ethnographic method. The data in this study are the prose and poetry of the people of the Rejang tribe, Muara Kemumu Subdistrict, Kepahiang Regency. Data is analyzed following the principle of transfer of ideas rather than translating word by word. The results showed that there were seven folk prose and 13 folk poems in Muara Kemumu District, Kepahiang Regency. The people's prose in Muara Kemumu District are: (1) The Origin of Stone Necklace, (2) Wak Wir Ghost, (3) Benuang Sakti, (4) Bloloi, (5) The Origin of Rejang Pat Petulai, (6) Origin Corn Fruit, (7) Kancil Ingkar Janji. The people's poems in Muara Kemumu District are in the form of: rhymes, traditional expressions (proverbs), and incantations which the authors have grouped according to Danadjaja's guidelines.
\end{abstract}

Keywords: Prose, folk poetry, Rejang tribe, Kepahiang. 


\section{PENDAHULUAN}

Prosa merupakan karya sastra yang disajikan dalam bentuk cangkokan, yakni dialog kedalam monolog (Kosasih, 2012: 36). Dalam perkembangannya prosa merupakan satu ragam (genre) yang cukup dikenal masyarakat selain puisi. Pada mulanya prosa berkembang sebagai bagian dari tradisi lisan masyarakat yang tumbuh dan berkembang dalam cerita dari mulut ke mulut atau turun menurun secara berantai. Cerita rakyat merupakan bagian dari prosa yang terbagi ke dalam beberapa bagian di antaranya, hikayat, dongeng, legenda, mite dan lain sebagainya.

Macculoch (1997:36) menyatakan cerita rakyat adalah bentuk tertua dari sastra romantik dan imaginatif, fiksi tak tertulis dari manusia masa lampau dan manusia primitif di semua belahan dunia. Selain cerita rakyat ada juga yang di sebut puisi. Puisi adalah keindahan yang menjelma dalam kata-kata. Puisi tidak menjadi indah karena kata-kata, sebaliknya puisi kata-kata menjadi indah karena puisi yang dikandungnya. Namun, puisi rakyat tidak perlu dibicarakan secara khusus karena perbedaannya hanya terletak pada bentuk bahasanya saja yang bersajak, sedangkan isinya sama saja dengan cerita rakyat. Oleh karena puisi rakyat pada waktu dibawakan selalu disertai dengan nyanyian, maka puisi rakyat dapat digolongkan ke dalam genre nyanyian rakyat. Puisi rakyat dapat berbentuk macam-macam, antara lain dapat berbentuk ungkapan tradisional (peribahasa), pernyataan tradisional (tekateki), pantun, cerita rakyat dan kepercayaan rakyat yang berupa mantra-mantra.

Setiap daerah yang ada di Indonesia bahkan di belahan dunia banyak memiliki tradisi kebudayaan dan karya sastra yang berbeda antara yang satu dengan yang lainnya. Akan tetapi, sangat disayangkan generasi muda atau penerus bangsa saat ini sudah tidak tertarik untuk menggali lebih dalam lagi budaya daerahnya sendiri, mereka lebih tertarik untuk menggali budaya luar sehingga penelitian sastra daerah masih sedikit atau jarang di teliti khususnya di daerah Provinsi Bengkulu.

Provinsi Bengkulu adalah salah satu daerah yang cukup kaya akansastranya. Khususnya sastra lisan, mitos, legenda, dongeng, puisi rakyat dan sebagainya. Beberapa sastra lisan yang berkembang di Provinsi Bengkulu dalam bentuk legenda antara lain yaitu Putri Gading Cempaka. Sastra lisan juga berkembang luas di daerah-daerah Bengkulu yang terbagi atas beberapa Kabupaten. Salah satu Kabupaten yang memiliki sastra lisan yang lahir dari folklore adalah Kabupaten Kepahiang.

Kabupaten Kepahiang adalah bagian dari wilayah Provinsi Bengkulu yang merupakan pemekaran dari Kabupaten Rejang Lebong dan dibentuk berdasarkan Undang-undang No. 39 Tahun 2003. Secara geografis Kabupaten Kepahiang terletak di bagian Dataran Tinggi Bukit Barisan dengan Koordinat 339'05"LS 10234'42"BT / 3,651431응 102,578201으. Masyarakat yang tinggal di Kabupaten Kepahiang adalah suku Jawa, Sunda, Serawai dan Rejang, tetapi mayoritas masyarakat yang tinggal di Kabupaten itu adalah suku Rejang. Masyarakat rejang yang tinggal di KabupatenKepahiangmulaidariKecamatanB ermanillirsampaipadaKecamatanMerigi.

Mayoritas penduduk rejang yang tinggal di Kepahiangitubermatapencaharian sebagai petani karena daerah itu merupakan daerah yang cocok untuk berkebun.

Dari beberapa Kecamatan yang ada di KabupatenKepahiang, Kecamatan Muara Kemumu merupakan salah satu daerah yang menyimpan prosa dan puisi rakyat yang cukup menarik untuk diteliti. Tidak hanya satu prosa dan puisi rakyat, namun terdapat beberapa prosa dan puisi rakyat karena setiap desa yang ada di Kecamatan Muara Kemumu mempunyai prosa dan puisi rakyat yang tentunya mempunyai keunikan tersendiri. Adapun nama-nama 
desa yang ada di Kecamatan Muara Kemumu adalah: Batu Bandung, Batu Kalung, Limbur Baru, Sosokan Baru, Sosokan Tabah, danTalang Tige yang memilik isuatu cerita yang ternama dan dianggap bersejarah sebagai asal muasal penamaan suatu tradisi, nama suatu tempat dan kepercayaan setempat.

Berdasarkan pemaparan di atas maka, timbulah ketertarikan peneliti untuk mengetahui prosa dan puisi rakyat yang ada di Kecamatan Muara Kemumu Kabupaten Kepahiang dengan cara mengumpulkan prosa dan puisi rakyat di daerah tersebut.

\section{METODE}

Metode yang digunakan dalam penelitian ini adalah metode Etnografi. Etnografi adalah metode untuk menangkap sudut pandang yang asli. Dalam penelitian ini peneliti melibatkan diri dalam masyarakat tertentu untuk jangka waktu yang cukup lama, mengamati, bertanya dan mendengarkan apa yang dibicarakan orang. Peneliti mengumpulkan data yang telah diperoleh di tempat kejadian, yang akan memberikan jawaban pada masalah yang sedang dipertanyaakan (Spradley, 1997:3).

Penelitian ini dilakukan di beberapa lokasi yang ada di Kecamatan Muara Kemumu Kabupaten Kepahiang pada bulan April sampai Mei antara lain: Desa Batu Bandung, Desa Batu Kalung, Desa Limbur Baru, Desa Sosokan Baru, Desa Talang Tige, dan Desa Sosokan Taba.

Teknik pengumpulan data yang penulis gunakan dalam penelitian ini antara lain: Inventarisasi, wawancara, dan rekaman. Teknik analisis data yang digunakan dalam penelitin ini antara lain: Mentranskripsi data, Menerjemahkan, mengklasifikan data, dan menginterprestasi.

\section{HASIL DAN PEMBAHASAN}

Pada zaman modern ini, prosa dan puisi rakyat sebagai sastra lisan yang di turun-temurunkan sudah dianggap kuno dan ketinggalan zaman oleh anak-anak di Kecamatan Muara Kemumu. Beberapa orang pun telah hanyut dalam arus modernisasi. Meskipun begitu masih terdapat orang-orang tua yang memiliki kepercayaan dalam melestarikan sastra daerah berupa prosa dan puisi rakyat. Akan tetapi sangat disayangkan, kebiasaan bercerita atau bersastra lisan ini pun sudah sangat jarang lagi dilaksanakan, hal ini disebabkan oleh masyarakat lebih tertarik dengan kemajuan-kemajuan teknologi yang telah ada baik itu media cetak maupun media elektronik.

Di Kecamatan Muara Kemumu prosa dan puisi rakyat mulai sulit dijumpai hal itu dikarenakan kurangnya pengetahuan generasi muda suku Rejang terhadap sastra yang ada di daerah mereka sendiri, khususnya jenis sastra yang berupa prosa dan puisi rakyat. Semua jenis dan bentuk sastra lisan pada hakikatnya mengandung ajaran atau petunjuk bagi masyarakat kebudayaannya sehingga semua jenis dan bentuk sastra lisan (prosa dan puisi; legenda, dongeng, sage, fabel, pantun, mantra, dan lainnya) dapat dinilai sebagai bentuk-bentuk yang mengandung ajaran dan bersifat sejarah dalam masyarakat Kecamatan Muara Kemumu.

Berdasarkan hasil penelitian yang telah penulis lakukan di berbagai desa di Kecamatan Muara Kemumu pada bulan April sampai Mei 2018 yang dibantu oleh kepala desa masing-masing wilayah di Kecamatan Muara Kemumu penulis mendapatkan delapan prosa rakyat. Namun, ada satu cerita yang tidak termasuk ke dalam prosa rakyat. Cerita itu pada intinya mengisahkan struktur pemerintahan desa dari awal terbentuknya desa tersebut. Oleh karena itu, penulis hanya menganalisis tujuh prosa dan 13 puisi rakyat yang telah penulis kelompokkan berdasarkan jenisjenisnya sesuai panduan Danandjaja dalam penelitian etnografi. 
Pada penelitian ini penulis mendapat kendala yang membatasi penulis untuk mendapatkan informasi mengenai prosa dan puisi rakyat. Keadaan informan yang kurang memungkinkan untuk diwawancarai menjadi kendala bagi penulis untuk mendapatkan lebih banyak informasi. Usia dan kemampuan berkomunikasi dari informan menjadi masalah yang tidak dapat diatasi oleh penulis. Dalam hal ini penulis telah berusaha untuk mencari informan lain, namun karena kurang dilestarikannya sastra di daerah tersebut maka tidak ada informan yang usianya lebih muda mengetahui sastra yang mereka miliki. Itulah sebabnya penulis hanya menganalisis tujuh dari delapan prosa rakyat dan 13 puisi rakyat yang penulis dapatkan.

Berikut ini penulis akan mengelompokkan prosa dan puisi rakyat di Kecamatan Muara Kemumu yang telah penulis dapatkan. Pengelompokkan ini berdasarkan ciri-ciri yang dimiliki oleh masing-masing data. Prosa dan puisi rakyat tersebut mengandung berbagai hal menyangkut kehidupan keseharian masyarakat di Kecamatan Muara Kemumu yang merupakan sejarah bagi masyarakat pemiliknya berdasarkan jenis-jenis sesuai panduan Danandjaja.

\section{Prosa rakyat di Kecamatan Muara Kemumu}

Dari hasil penelitian yang telah dilakukan pada bulan April sampai Mei 2018, penulis mendapatkan prosa rakyat yang telah dikelompokkan berdasarkan jenis-jenis prosa rakyat. Adapun, jenis prosa yang penulis dapatkan di Kecamatan Muara Kemumu sebagai berikut :

\section{Asal Mula desa Batu Kalung}

Dalam cerita Asal Usul desa Batu Kalung menjelaskan bahwa terbentuknya desa Batu Kalung berasal dari perempuan yang dikutuk oleh Sipahit Lidah menjadi sebuah batu karena perempuan itu tidak menjawab pertanyaan Sipahit Lidah. Meskipun demikian, sampai saat ini masyarakat disana tidak mengetahui secara pasti keberadaan batu tersebut. Namun, masyarakat tetap percaya jika peristiwa itu benar-benar terjadi.

Cerita ini dimasukkan ke dalam golongan legenda setempat karena cerita ini merupakan suatu peristiwa yang berhubungan dengan suatu tempat, nama tempat, dan bentuk topografi, yakni bentuk permukaan suatu daerah, apakah bukitbukit, berjurang atau sebagainya.

Cerita Asal Usul desa Batu Kalung peristiwa terjadinya sudah begitu lampau. Cerita ini terjadi di kehidupan yang nyata dan memiliki nilai-nilai sosial yang baik untuk diajarkan orang tua terhadap anakanaknya. Selain itu, cerita ini merupakan sebuah cerita yang melegenda bagi masyarakat penuturnya dan sudah menyebar ke daerah-daerah lain sehingga dapat dikenal luas di daerah lainnya.

\section{Cerita Hantu Bawah/Wak Wir}

Dalam cerita ini dijelaskan Wak Wir adalah hantu yang senang sekali berkeliaran disaat malam hari, dia selalu mencari mangsa berupa anak-anak yang badannya kedinginan. Setiap menjelang malam tiba Wak Wir akan masuk kedalam pondok-pondok warga secara bergantian.

Cerita ini dimasukkan ke dalam golongan legenda alam gaib dalam legenda ini berbentuk kisah yang dianggap benarbenar terjadi dan pernah dialami seseorang. Fungsi legenda ini adalah untuk meneguhkan kebenaran "takhyul" atau kepercayaan rakyat, walaupun legenda alam gaib ini merupakan pengalaman pribadi seseorang, namun isi pengalaman itu mengandung banyak motif cerita tradisional yang khas ada pada kolektifnya.

Selain itu, legenda ini pun bertujuan untuk memperingatkan orang tua agar menutup pintu dan jedela pada saat malam tiba dan membuat rumah tetap hangat 
dengan cara menghidupkan api. Hal ini dilakukan agar Wak Wir tidak menghampiri rumah mereka. Sebagian masyarakat di desa Batu Kalung masih mempercayai dan melakukan hal tersebut hingga saat ini. Dalam legenda ini juga terdapat ajaranajaran yang berguna meningkatkan kedisiplinan yang baik untuk diajarkan orang tua terhadap anaknya.

\section{Cerita Benuang Sakti}

Cerita ini diyakini benar-benar terjadi karena penduduk meyakini bahwa asal mula daerah Bermani atau bagian dari daerah mereka berdasarkan awal mula cerita yang mencerikan tentang sebuah batang pohon bernama Benuang Sakti yang ditebang dan dijaga oleh seekor harimau dan rusa.

Legenda setempat yang berhubungan erat dengan nama suatu tempat adalah cerita Benuang Sakti. Seperti diketahui, Benuang sakti adalah nama sebatang pohon yang di tebang dan membentuk suatu wilayahyaitudaerahBermani. Cerita ini dimasukkan ke dalam golongan legenda setempat karena merupakan suatu peristiwa yang dianggap benar-benar terjadi oleh masyarakat Rejang, khususnya di desaTalangTige.Selain dari itu cerita ini merupakan peristiwa bersejarah bagi masyarakat sekitar.

\section{Puisi rakyat di Kecamatan Muara Kemumu}

Dari hasil penelitian yang telah dilakukan pada bulan April sampai Mei 2018, penulis mendapatkan puisi rakyat yang telah dikelompokkan berdasarkan jenis puisi. Adapun, jenis puisi rakyat yang penulis dapatkan di Kecamatan Muara Kemumu sebagai berikut :

\section{Pantun dari desa Batu Bandung ke-1}

Pantun ini dikenal oleh informan ketika ia masih kecil. la sering mendengar orang mengatakan itu saat di sekolah dan saat terdapat acara-acara tertentu seperti musyawarah adat dan sebagainya. Fungsi pantun ini sebagai alat yang dilontarkan ketika terdapat masalah yang belum bisa di selesaikan secara musyawarah. Dulunya pantun ini diciptakan berdasarkan cerita yang terjadi antara desa Batu Bandung dan desa Sosokan Baru. Desa Sosokan Baru merupakan perpecahan dari desa Batu Bandung, dimana masyarakat desa Sosokan Baru tidak dapat menerima sistem pemerintahan yang berlaku, sehingga mereka memutuskan untuk memisahkan diri dari desa Batu Bandung dan membuat desa baru yaitu Sosokan Baru.

\section{Pantun dari desa Limbur Baru ke-1}

Pantun ini merupakan salah satu puisi pertama di desa Limbur Baru yang sudah diajarkan secara turun menurun oleh masyarakat sekitar, puisi tersebut mengandung pelajaran sebagai sindiran untuk orang-orang tertentu yang lupa akan kehidupannya terdahulu. Pantun ini informan dapatkan dari kedua orang tuanya.

\section{Pantun dari desa Sosokan Taba}

Pantun ini biasa diucapkan saat mempelai laki-laki akan mengajak mempelai wanita yang telah dinikahinya untuk tinggal bersama keluarga mempelai laki-laki tersebut. Sebelum mempelai wanita pindah bersama keluarga mempelai laki-laki biasanya penduduk setempat mengadakan sebuah syukuran. Maksud dari pantun itu, jika mempelai wanita yang telah dinikahinya tadi belum bisa menjadi pasangan yang baik, maka pihak mempelai laki-laki diminta untuk membimbingnya. Sampai saat ini pantun itu masih sering digunakan pada acara syukuran tersebut.

\section{Pantun dari desa Sosokan Baru ke-1}

Pantun ini dulunya sering diucapkan oleh pemuda-pemudi setempat sebagai salah satu ungkapan kekecewaan atas cinta yang tidak diterima oleh pasangan yang 
disukainya.Pantun tersebut telah diajarkan secara turun-menurun oleh orang tua mereka pada zaman dahulu. Pantun ini mengibaratkan sebuah ungkapan kekecewaan karena cintanya ditolak oleh seseorang yang disukai oleh penutur pantun tersebut. Namun, seiring perkembangan zaman pantun tersebut sudah tidak dituturkan lagi oleh masyarakat setempat.

\section{Ungkapan tradisional (peribahasa) dari desa Batu Bandung ke-1}

Di daerah Batu Bandung ungkapan tradisional (peribahasa) biasanya disampaikan pada saat acara tertentu seperti acara keluarga, pertemuan tokohtokoh adat. Adapun maksud peribahasa di atas adalah sebagai permintaan maaf dari tuan rumah atau yang mempunyai acara atas tutur kata yang diucapkan kepada tamu sekaligus keluarga yang menghadiri acara tersebut. Pribahasa ini biasanya disampaikan sebelum atau sewaktu acara dimulai.

Sampai saat ini ungkapan tradisional (peribahasa) ini masih di lestarikan oleh masyarakat Batu Bandung. Namun, hanya sebagian masyarakat saja yang masih menggunakan ungkapan tradisional tersebut.

\section{Ungkapan tradisional (peribahasa) dari desa Sosokan Taba}

Puisi rakyat ini digolongkan ke dalam bentuk ungkapan tradisional (peribahasa) yang digunakan pada zaman dahulu sebagai alat untuk memutuskan pendapat saat melakukan prosesi pelamaran. Biasanya ungkapan tradisional itu diucapkan oleh pihak perempuan terlebih dahulu dan harus di jawab langsung oleh pihak laki-laki.

Pada zaman dahulu ungkapan tradisional (peribahasa) seringkali muncul secara tiba-tiba tanpa diciptakan ataupun disusun kata perkata terlebih dahulu.
Bilamana dipihak perempuan mengucapkan sebuah ungkapan tradisional (peribahasa) pihak laki-laki harus membalas sesuai dengan konteks yang sedang dibahas. Jika tidak langsung dibalas ungkapan yang diucapkan oleh pihak perempuan maka akan terjadi sebuah kekacauan yang menyebabkan acara pelamaran tersebut gagal.

\section{Mantera dari desa Talang Tige}

Puisi rakyat ini digolongkan kedalambentukmanterakarenakeberadaann yadianggap memiliki kekuatan gaib. Bagi masyarakat penuturnya, mantra merupakan salah satu cara yang dipercayai mampu mengendalikan sesuatu. Mantera di atasadalah salah satunya yang hingga saat ini masih terus dipelajari dan digunakan oleh masyarakat setempat.

Manterainibersifatmistis dan tidak dapatdiberikankepadasembarang orang karenadikhawatirkan

disalahgunakan.Menurutkepercayaanmerek amantera di atasmampu menghilangkan rasa takut.Manteratersebuttidaksembarang orang dapat menggunakannya karena dalam proses penggunaannya terdapat syarat-syarat tertentu.

\section{Mantera dari desa Limbur Baru}

Puisi rakyat ini digolongkan ke dalam bentuk mantera karena termasuk sejenis puisi tua yang keberadaannya dianggap memiliki kekuatan gaib sebagaimana doa. Mantera di atas merupakan mantera yang asli berasal dari desa Limbur baru. Menurut masyarakat setempat, mantera tersebut dapat digunakan untuk menghilangkan guna-guna (santet). Namun, mantera tersebut tidak sembarang orang dapat mengguanakannya.

Desa Limbur Baru merupakan desa Sapu Jakat, masyarakat setempat masih mempercayai hal tersebut, hingga saat ini mantera tersebut masih terus dilestarikan. Namun dalam menggunakannya, mantera 
tidak dapat berfungsi jika belum ada pelajaran-pelajaran mengenai pendahulunya.

\section{PENUTUP}

Kesimpulan

Berdasarkan penelitian yang telah dilakukan oleh penulis mengenai prosa dan puisi rakyat di Kecamatan Muara Kemumu Kabupaten Kepahiang adalah tujuh prosa rakyat dan tiga belas puisi rakyat. Adapun prosa rakyat yang terdapat di Kecamatan Muara Kemumu adalah : (1) Asal Mula Batu Kalung, (2) Hantu Wak Wir, (3) Benuang Sakti, (4) Bloloi, (5) Asal Usul Rejang Pat Petulai, (6) Asal Usul Buah Jagung, (7) Kancil Ingkar Janji. Adapun puisi rakyat yang terdapat di Kecamatan Muara Kemumu adalah berupa: pantun, ungkapan tradisional (peribahasa), danmantera.

Adapun bentuk-bentuk prosa dan puisi rakyat penulis kelompokkan ke dalam jenis masingmasingsesuaipanduanDanandjaja, yaitu :

1. Prosa rakyat Kecamatan Muara Kemumu a. Kelompok legenda ada dua jenis yaitu :

1. Legenda ada satu yaitu: (1) Asal usul Buah Jagung. Cerita ini termasuk ke dalam legenda karena menceritakan suatu kejadian yang sungguh-sungguh benarterjadidanditokohimanusia yang mempunyai sifat-sifat yang luar biasa.

2. Legenda setempat ada tiga yaitu: (1) Asal Mula Batu Kalung, (2) Benuang Sakti, (3) Asal usulRejang Pat Petulai. Cerita ini termasuk ke dalam golongan legenda setempat karena menceritakan asal usul terbentuknya suatu tempat atau wilayah.

3. Legenda alam gaib ada dua yaitu: (1) HantuWakWir, (2) Bloloi. Cerita ini termasuk ke dalam golongan legenda alam gaib karena ceritanya benar-benar pernah terjadi dan dialami oleh masyarakat setempat.

b. Kelompok dongeng yaitu: (1) Kancil Ingkar Janji. Cerita ini termasuk ke dalam golongan dongeng karena menceritakan sesuatu yang bukan sebenarnya, hanya sebagai hiburan yang di dalamnya terdapat pelajaran moral.

2. Puisi rakyat Kecamatan Muara Kemumu

a) Kelompok Pantun terdapat delapan pantun masing-masing satu dari desa Sososkan Taba, dua dari desa Limbur Baru, dua dari desa Sosokan Baru, dan tiga dari desa Batu Bandung.

b) Kelompok Ungkapan tradisional (peribahasa) terdapat tiga ungkapan tradisional masingmasing dari desa Batu Bandung dan desa Sosokan Taba.

c) Kelompok mantera terdapat dua mantera masing-masing dari desaTalangTige dan desa Limbur Baru.

Saran

Sehubungan dengan hasil yang telah dilakukan, maka peneliti menyarankan :

1. Perludiadakanpembinaan, pengembangan dan pelestarian sehingga dapat memperkaya dan menambah khazanah kebudayaan nasional.

2. Kepada orang tua yang lebih ahli dalam bercerita dan berpantun hendaknya memperkenalkan hal tersebut pada generasi berikutnya. Demikian pula hendaknya guru-guru Bahasa Indonesia diharapkan dapat memperkenalkan cerita-cerita yang terdapat di daerah agar siswa tidak merasa asing lagi dengan budaya yang dimiliki oleh daerahnya. 
DAFTAR PUSTAKA

Adriyetti, Amir. 2013. Sastra Lisan Indonesia. Yogyakarta: Perpustakaan Nasional.

Danandjaja, James. 1991. Folklor Indonesia: IImu Gosip, Dongeng dan Lain-lain Cetakan IV. Jakarta: PT Pustaka Utama Grafiti.
Endraswara, Suwardi. 2013. Metodologi Penelitian Sastra: Konsep, Teori, dan Aplikasi. Yogyakarta: Medpress.

Spradley, James P. 1997. Metode Etnografi. Yogyakarta: PT Tiara Wacana Yogya.

Zaidan, Abdul Rozak. 2002. Pedoman Penelitian Sastra Daerah. Jakarta: Pusat Bahasa. 